Soner Algı

Necmettin Erbakan University, soneralgi@hotmail.com, Konya-Turkey

http://dx.doi.org/10.12739/NWSA.2017.12.2.D0190

ÖZENGEN MÜZİK EĞİTIMI VEREN KURUMLARDA BAĞLAMA ÖĞRETIM YÖNTEMLERİ (KONYA İLI ÖRNEĞİ)

Öz

Günümüzde ülkemizin hemen hemen her ilinde çalgı eğitimiyle ilgili özengen müzik eğitimi kurumları açılmakta ve faaliyet göstermektedir. Bu kurumlarda bağlama, gerek kendi halk ezgilerimizin seslendirilmesi gerekse halk ezgilerimiz dışında başka müzik türlerinin icrasında etkin bir şekilde kullanılması sebebiyle yoğun bir şekilde ilgi görmüş ve tercih edilmiştir. Bu bağlamda genel ve mesleki müzik eğitiminde olduğu gibi özengen müzik eğitiminde de bağlama öğretim yöntemlerinin yeterliliği önem kazanmaktadır. Bu çalışma Konya'da bulunan özengen müzik eğitimi kurumlarında uygulanan bağlama öğretim yöntemlerinin incelenmesini hedeflemiştir. Araştırmayla ilgili Konya'da ulaşılabilen özengen müzik eğitimi veren kurumlarda görev yapmakta olan 7 bağlama eğitmenine 15 açık uçlu sorudan oluşan bir anket uygulanmıştır. Anketten elde edilen bulgular ışığında sonuçlar ve öneriler hazırlanmıştır.

Anahtar Kelimeler: Bağlama, Bağlama Öğretimi, Müzik Eğitimi, Türk Halk Müziği, Özengen Müzik Eğitimi

\title{
BAGLAMA TEACHING METHODS IN AMATEUR MUSIC EDUCATION INSTITUTIONS (KONYA EXAMPLE)
}

\section{ABSTRACT}

Today, in almost every province of our country, private music education institutions related to instrument education are opened and operating. In these institutions, baglama has been attracted and preferred because of the fact that our folk songs must be vocalized and that other types of music other than our folk songs are used effectively in the performances. In this context, as in general and professional music education, baglama teaching methods are gaining importance in music education. This study aimed to examine baglama teaching methods applied in amateur music education institutions in Konya. A questionnaire consisting of 15 open-ended questions was applied to 7 baglama instructors who are working in organizations that provide amateur music education in Konya. Results and suggestions were prepared in the light of findings obtained from the questionnaire.

Keywords: Baglama, Baglama Education, Music Education, Turkish Folk Music, Amateur Music Education 


\section{GÍRISS (INTRODUCTION)}

Müzik eğitimi; bireylerin ruhsal doygunlukla, zeki, mantıklı, becerili ve çağdaş bir toplum halinde hayatlarını sürdürebilmeleri için olmazsa olmazıdır. Müzik eğitimi yoluyla elde edilen müziksel davranışlar, insanı insani değerler içerisine sevk eden bir olgudur. "Müzik eğitimi bireye kendi yaşantısı yoluyla amaçlı olarak belirli müziksel davranışlar kazandırma, bireyin müziksel davranışını kendi yaşantısı yoluyla amaçlı olarak değiştirme ya da bireyin müziksel davranışında kendi yaşantısı yoluyla amaçlı olarak belirli değişiklikler oluşturma ve geliştirme sürecidir" (Uçan, 1997:8). "Müzik eğitimi yoluyla birey ile çevresi, özellikle müziksel çevresi arasındaki etkileşimin daha düzenli, daha sağlıklı, daha etkili ve daha verimli olması beklenir" (Uçan, 2005:24). Bilindiği gibi müzik eğitiminin genel müzik eğitimi, özengen müzik eğitimi ve mesleki müzik eğitimi olmak üzere üç temel boyutu vardır:

Genel müzik eğitimi; "sağlıklı insanca bir yaşam için ayrım gözetmeksizin herkese yönelik, asgari-ortak genel müzik kültürünü kazandırmayı amaçlayan müzik eğitimi türüdür" (Tarman, 2006:9). "İşmeslek, bölüm, kol-dal ve program türü ne olursa olsun, ayrım gözetmeksizin, her düzeyde, her aşamada, her yaşta herkese yönelik olup, sağlıklı ve dengeli bir insanca yaşam için gerekli asgari-ortak müzik kültürünü kazandırmayı amaçlar" (Uçan, 1997:31) .

Özengen müzik eğitimi; "müziğe ya da müziğin belli bir dalında özengence (amatörce) ilgili, istekli ve yatkın olanlara yönelik olup, etkin bir müziksel katılım, zevk ve doyum sağlamak ve bunu olabildiğince sürdürüp geliştirmek için gerekli müziksel davranışlar kazandırmayı amaçlar" (Uçan, 1997:31). "Açıklamadan anlaşılacağı üzere özengen müzik eğitimi, bu isi profesyonel ya da mesleki anlamda değil, yalnızca müziğe hobi olarak hayatında yer veren bireylere yönelik verilen bir eğitim sistemidir" (Özdek, 2006:14-15). "Genel müzik eğitimi alanlarındaki disipliner anlayış, özengen müzik eğitiminde de kısmen yer almaktadır. Kendine has bir çalışma etiğine de sahip olduğu düşünülen bu alan, sanata hayatın içerisinde amatör bir ruhla yer vermenin önemini anlamak ve bunu faaliyete geçirmek için kullanılmaktadır" (Özdek, 2012:1094).

Mesleki müzik eğitimi; "müzik alanının bütününü, bir kolunu ya da dalını, o bütün, kol ya da dal ile ilgili bir işi meslek olarak seçen, seçmek isteyen, seçme eğilimi gösteren, seçme olasılığı bulunan ya da öyle görünen müziğe belli düzeyde yetenekli kişilere yönelik olup, dalın, işin ya da mesleğin gerektirdiği müziksel davranışları ve birikimi kazandırmayı amaçlar" (Uçan, 2005:31). "Müzikte birçok dalda iş, müziğin mesleki eğitim boyutu kullanılarak elde edilir. Müzik sanatında bestecilik, yorumculuk, müzik bilimciliği, müzik öğretmenliği, müzik teknoloğu mesleki müzik eğitimi alanı kullanılarak elde edilen branşlardır. Bu anlamda müziğe mesleki eğitimde kullanım alanı açan kurumlar ise Konservatuarlar, Güzel Sanatlar Liseleri, Eğitim Fakülteleri Müzik Eğitimi Bölümleri, Güzel Sanatlar Müzik Bilimleri bölümleridir" (Tanrıöver ve Başaran Tanrıöver, 2015:558) .

Müzik eğitimini oluşturan en önemli kaynak çalgı eğitimidir. Çalgı eğitimi, bireye çalgısında yetenek ve becerilerini daha derli toplu hale getirerek geliştirmesi için sistemli ve amaçlı olarak davranış değişikliği kazandırma sürecidir. Bununla beraber çeşitli kaynaklarda çalgı eğitimi ile ilgili tanımlamalar şu şekilde ifade edilmiştir:

- "Çalgı eğitimi, insanın kendisini yakından tanıyabilmesi, var olan yeteneklerini anlayabilmesi, eğitim aracılığıyla mevcut becerilerini geliştirip, yeni beceriler elde edebilmesi ve bu sayede kendisini gerçekleştirebilme şansı veren bir uğraş 
olmasından dolayı müzik eğitiminin önemli bir koludur" $\overline{\text { (Uslu, }}$ 1996:1).

- "Çalgı eğitimi temelde bir çalgıyı çalabilmeyi öğrenebilme, geliştirebilme ve en etkili biçimde kullanabilme gibi amaçları kapsamaktadır. Bilgiyi işleme sürecinin ve bilgiyi işleme modelinin doğru ve etkin kullanılması, bu amaçlara ulaşmada önemli bir yere sahiptir" (Kurtuldu, 2005:261).

- "Çalgı eğitimi, bir çalgının çalınabilmesinde uygulanan, yöntemler bütünüdür. Bireysel olarak yapılan çalgı eğitiminde öğrencilere, çalgısını doğru bir teknikle çalma, çalışma süresini verimi arttıracak şekilde ayarlama, müzik kültürlerini çalgısı yoluyla en iyi şekilde kavratma ve müzikal becerilerini arttırmaya yönelik çalışmalar, çalgı eğitiminin başlıca amaçlarıdır" (Parasız, 2009:4).

- "Çalgı eğitimi, uzun ve zorlu bir yol olmakla birlikte aynı zamanda özenli, sabırlı ve planlı çalışma gerektiren bir süreçtir. Bu zorlu yoldaki en önemli iki unsur ise öğrenci ve öğretmendir. Bireysel olarak yapılan çalgı eğitimi derslerinde öğretmen öğrenci iletişimi ve öğretim yöntemi, hedeflenen davranışları edinme sürecinde etkin bir rol oynar. Çalgı eğitiminde kullanılacak olan eserler, çalgının yapısına uygun olarak belirlenmeli ve öncelikle ulusal müziklerimiz çalgl eğitiminde kullanılmalıdır" (Parasız, 2009:19).

Halk müziğimizin temel çalgısı olan bağlama, geçmişten günümüze kültürümüzü aktarmada rolünü başarılı bir şekilde gerçekleştirmiş ve sürdürmektedir. Ülkemizin her yöresinde gerek yöre ezgilerinin gerekse yöresel ezgilerin dışında birçok müzik türünün icrasında etkin bir şekilde kullanılmaktadır. Bă̆lama, ülkemizde en geniş alana yayılabilmiş ve geçmişten günümüze usta-çırak yöntemiyle hem şekli hem de çalınış biçimleri itibariyle değişim ve gelişim göstermiştir. Ege'de zeybekler, Akdeniz'de teke havaları, Orta Anadolu'da bozlaklar, Karadeniz'de Karadeniz havaları gibi ülkemizin her yöresine hitap edebilmiş ve yöresel çalınış stilleriyle her yörenin kültürünü etkin bir şekilde günümüze kadar aktarmıştır. Bağlamanın günümüzde artık daha geniş kitlelere hitap etmesi ve yöresel ezgilerin yanı sıra farklı müzik formlarının icrasında da kullanılması çalgıya karşı ilgiyi oldukça artırmış görülmektedir. Günümüzde bağlama çalım teknikleri konusunda büyük ilerleme kaydedilmesi, yeni tekniklerin keşfedilmesi ve özellikle destekleyici egzersiz ve etütlerin üretilmesi çalgıya artan ilginin diğer sebepleri olarak söylenebilir. Bă̆lama eğitimi, Türkiye'de geleneksel çalgılar içerisinde en yaygın biçimde ve uzun zamandır sürdürülen eğitim alanıdır. Bunun en temel nedeni ise bağlamanın geleneksel çalgılar içerisinde en çok sevilen, bilinen ve çalınan bir çalgı olmasıdır. Bă̆lama, çalış tekniklerindeki incelik, yöresel unsurları içermesi, virtüoziteye uygun bir çalgı olması ve kendine özgü ifade biçimleri ile zengin bir çalışma sahasına sahiptir. Bağlamaya özgü tavırlar düzenler ve çalış biçimlerinin yanı sıra diğer geleneksel çalgılardan farklı olarak şelpe adı verilen elle çalış şekli ve tezeneli olmak üzere iki temel çalış tekniğine sahiptir. Bu iki çalış tekniği içerisinde gerek repertuarı gerekse çalıma uygunluğu açılarından tezene ile çalma tekniği Türkiye genelinde en yaygın çalış biçimidir. Bunun yanında zengin bir yöresel tezene tavrına sahip olması ve bu tavırların çalıma uygunluğunun gereği dolayısıyla, uzun saplı bağlama, daha geniş bir kullanım alanına sahiptir (Kınık, 2010:50).

Ülkemizde bağlama eğitimi, mesleki müzik eğitimi veren birçok üniversitenin Devlet Konservatuvarları, Güzel Sanatlar Fakülteleri ve Eğitim Fakültelerine bağlı Müzik Eğitimi Anabilim Dalları'nda bireysel 
çalgı vb. isimlerde verildiği bilinmektedir. Bu kurumların dışında pek çok il ve ilçelerde özengen müzik eğitimi kurumlarında da bağlama öğretimi devam etmektedir. Özengen müzik eğitimi kurumlarında ortalama 6 yaş üstünde hemen hemen her yaş grubuna bireysel ya da toplu olarak bağlama öğretimi verilmektedir. Yukarıda bahsi geçen sebeplerle çalgıya olan ilginin artması, yeni özengen müzik eğitimi veren kurumların açılmasına katkı sağlamaktadır. Günümüzde bağlama öğretimi özengen olarak halk eğitim merkezlerinde ve özel müzik eğitim merkezlerinde yaygın bir şekilde verilmektedir. Bağlama öğretiminin yaygın hale gelmesi beraberinde çalgının öğretiminin doğru verilip verilmediğinin önemini artırmaktadır. Bu doğrultuda araştırmanın problem cümlesi olarak "Konya'da özengen müzik eğitimi veren kurumlarda bağlama öğretim yöntemi olarak nasıl bir yol izlenmektedir?" denilebilir.

\section{2. ÇALIŞMANIN ÖNEMI (RESEARCH SIGNIFICATE)}

Çalışmanın giriş bölümünde de açıklandığı üzere ülkemizde bağlama kendi kültürümüzün çalgısı olması, halk müziğimizin dışındaki müzik türlerinde de kullanılabilirliği vb. birçok sebeple yoğun olarak istek duyulan ve tercih edilen bir çalgıdır. Dolayısıyla müzik eğitiminin her boyutunda olduğu gibi özengen olarak verilmesinde de çalgının öğretim yöntem ve tekniklerinin doğruluğu ve yeterliliği önem arz etmektedir.

\section{YÖNTEM (METHOD)}

Bu araştırmada tarama yöntemi kullanılmıştır. Araştırma örneklemi Konya'da özengen müzik eğitimi veren kurumlarda fiilen eğitmenlik yapmakta olan ve ulaşılabilen 7 bağlama eğitmeninden oluşmaktadır. Veriler anket veri toplama aracı kullanılarak elde edilmiştir. Anket açık uçlu 15 sorudan oluşmaktadır. Elde edilen verilerin analizinde sonuç ve öneriler hazırlanmıştır.

\section{BULGULAR VE TARTIŞMA (FINDINGS AND DISCUSSION)}

\subsection{Anketten Elde Edilen Bulgular (Findings from the Survey)}

Çalışmanın yöntem bölümünde de belirtildiği gibi Konya'da özengen müzik eğitimi veren kurumlarda fiilen eğitmenlik yapmakta olan ve ulaşılabilen 7 bağlama eğitmenine 15 sorudan (açık uçlu) oluşan anket uygulanmıştır. Bu anketten elde edilen veriler çalışmanın bu bölümünde açıklanmış ve yorumlanmıştır.

- Bağlama eğitmenliği yaptığınız kurumda bağlama dersi haftada kaç ders saati olarak verilmektedir ve bir ders kaç dakikadan oluşmaktadır?

E1: Haftada 1 ders saati (60 dakika) olarak yapılmaktadır.

E2: Haftada 1 ders olarak verilmektedir. 1 ders en az 100 dakika olarak verilmektedir.

E3: Bireysel dersler haftada 1 saat yapllmakta olup ders suresi 60 dakikadır.

E4: Kurumumuzda bağlama eğitimlerimiz haftalık 1 veya 2 ders saati olarak yapılmaktadır. Ders sürelerimiz 50 dakikadır.

E5: Her öğrenci için haftada 1 ders saati yapılmaktadır. Derslerin süresi 45 dakikadır.

E6: Çalıştığım kurum Gençlik Merkezi olduğu için haftada cumartesi ve pazar günleri toplu bir şekilde 10 saat verilmektedir. Bir ders saati 45 dakikadır.

E7: Çalıştığım kurum büyükşehir belediyesine bağlı meslek edindirme kursu (KOMEK) olduğu için bağlama dersleri haftada 8 saat verilmektedir. Bir ders saati 45 dakikadır. 
Bu soruya verilen cevaplara göre bağlama dersi haftada 1 ders saati olarak verildiği görülmektedir. Ders saati süreleri kurumlar arasında farklılık göstererek 50, 60 ve 100 dakika olarak belirtilmiştir. Ancak gençlik merkezi ve belediyeye bağlı Konya meslek edindirme kurslarında (KOMEK) 1 ders saati 45 dakika olmak üzere haftada 8 ile 10 ders saati şeklinde verilmektedir. KOMEK ve Gençlik Merkezi bünyesinde 1 ders saatinin aynı süre olması aynı müfredatın kullanıldığını göstermektedir. Diğer sorulara verilen cevaplardan da bu durum kesinlik kazanmaktadır.

- Bir haftalık bağlama ders sayısını ve bir dersin kaç dakika olduğunu neye göre belirliyorsunuz? Bu sürelerin yeterliliği ile ilgili düşünceleriniz nelerdir?

E1: Haftada 1 ders saatinin 60 dakika sürmesi özengen eğitim almakta olan öğrenciler için yeterli süre olması kanaatine geçmiş yıllarda haftada 2 ders süresi ders yapılması durumunda (özengen derslerde) öğrencilerin başarısına ekstra katkıda bulunmadığını düşünüyorum.

E2: Ders sürelerinde işlenen konunun teoriden hariç pratik uygulama gerektirdiği takdirde süre uzayabilir. Haftada bir ders işlenen konunun pratiğe döndürülmesi için yeterli bir zaman. Haftada iki ders konu tekrarı adına yapılabilir fakat günümüz teknolojisinin kayıt imkanları sayesinde öğrenci video kaydı aldığı konuyu kendi başına da işleyebiliyor.

E3: Haftalık ders sayısı öğrencilerin yeterlilik durumları göz önüne alınarak belirlenip öğrencinin talebi doğrultusunda artırılabilmektedir.

E4: Haftalık 1 ders saati çok yeterli değil ancak özel kurum olduğumuz için velilerinde talepleri doğrultusunda belirliyoruz.

E5: Ders sürelerini sanat merkezimiz belirliyor. Bence olumlu bir yaklaşım çünkü bir öğrencinin derse olan ilgisi ve konsantrasyonu araştırmalara göre en fazla 45 dakikadır.

E6: Gençlik Merkezi bünyesinde kurslarımızı açtığımız için toplamda 232 saat ders verilmektedir. Modül planına göre ders saatini ayarlıyoruz. Modül programına uygun ders işlemeye çalışıyoruz. Müfredatta 45 dakika olarak belirtilmektedir ancak ben dersimi verimli geçirip öğreteceğim türkü hedefine ulaşıncaya kadar ders saatini uzatıyorum. Sonuçta her öğrencinin seviyesi bir olmadığı için elimden geldiğince faydalı ders işleyip zamanı verimli kullanmaya özen gösteriyorum.

E7: Haftalık ders saatleri ve 1 ders saati halk eğitimi müfredatına göre belirleniyor. Ancak bir enstrüman dersi için 45 dakika yeterli bir zaman değil...

Bu soruya verilen cevaplara göre haftada 1 ders saati ve sürenin 60 dakika olarak verilmesinin yeterli olduğu görüşü hakimdir. Eğitmenler bu görüşle ilgili gerekçe olarak; geçmiş yıllarda haftada 2 ders saati yapılması durumunda öğrencilerin başarısına ekstra katkı sağlamadığını, öğrencilerin çoğunlukla video kaydı alarak ders yaptıkları için haftada ikinci bir derse gerek kalmadığını, ders saatinin en fazla 60 dakikayı geçtiğinde ilgi ve konsantrasyonun dağıldığını belirtmişlerdir. Bu görüşün haricinde 1 eğitmen haftada 1 ders saatinin yetersiz olduğunu ancak velilerin istekleri doğrultusunda belirlediklerini aktarmışlardır. Birinci soruda da bahsedildiği gibi KOMEK ve Gençlik Merkezi aynı müfredatı kullanmaktadırlar. Bu iki kurumun dışında diğer özel müzik eğitim kurumları ders saati ve sürelerini çeşitli sebeplerle değiştirebilmektedirler. 


\begin{tabular}{l}
\hline \hline Bağlama dersi almak isteyen öğrencilerin müziksel \\
kabiliyetlerinin yeterliliği ile ilgili herhangi bir ön test \\
yaplyor musunuz? Ön test yaplyorsanız içeriği hakkında bilgi \\
veriniz. Ön test cyapmlyorsanız yapmama sebeplerinizi \\
acrklayınız.
\end{tabular}

E1: Fiziksel bir uygunsuzluk olup olmadığı dışında özengen derslerde herhangi bir inceleme yapmayı tercih etmiyorum. Çünkü özengen müzik eğitiminde yeteneğin gerekli olduğunu düşünmüyorum. Öntest uygulamasını mesleki müzik eğitimi alan öğrencilerde uyguluyorum.

E2: Ne tarz müzik dinledikleri ile bir müzik eserinin sözlerine olan ilgilerini ölçüyoruz. Söz ezberleme alışkanlığı olan kişilerin enstrüman öğrenmekte avantajlı olduğu söylenebilir. Bunun haricinde ritim melodi tekrarı gibi birkaç küçük test yapılır.

E3: Öğrencilerin daha önce herhangi bir enstrüman eğitimi alıp almadığı sorulup almamışsa basit işitsel testler uygulanıyor.

E4: Merkezimizde tüm branşlarda yeterlilik testi uygulanıyor. Ritim tekrarı ve tek ses işitme testi uyguluyoruz.

E5: Öğrencinin müziksel kabiliyeti hakkında tabiki öntest yapıyorum. Öğrencinin müziksel duyumu daha sonra parmaklarını, bileğini ve reflekslerini gözlemliyorum. Bu öntest yaklaşık 2 hafta gibi bir süreyi buluyor.

E6: Ben gençlik merkezi bünyesinde ders verdiğim için bizim asıl amacımız müzisyen yetiştirmekten ziyade öğrencilerin boş vakitlerini faydalı bir uğraşla harcamalarını düşünülen birimde ders veriyorum. Bu açıdan yetenekli öğrenci yeteneksiz öğrenci diye bir test yapma durumumuz olmuyor malesef... Ancak ileride gerek güzel sanatlar liselerine gerek mesleki müzik eğitimi veren kurumlara yönlendirilebilecek öğrencilerin olup olmadığını tespit etmek amaçlı tek ses, aralık, ritim tekrarı gibi küçük çaplı öntest yapıyorum.

E7: Temel ve tekamül olmak üzere iki seviyede dersler veriliyor. Temel eğitim gruplarında her hangi bir sınav olmaksızın öğrenciler alınıyor. Tekamül gruplarında ise öğrencilerden daha önce birinci seviye kursunu (temel bağlama eğitimi) almış olması, nota okuma becerisi kazanmış olması ve nota eğitimi almamış ise de belirli bir seviyede yeteneğinin olmasına dikkat ediliyor.

Bu soruya verilen cevaplara bakıldığında 4 eğitmenin öntest yaptığı görülmektedir. Tek ses, aralık gibi küçük işitme testleri, basit ritim tekrarı, nota okuma bilgisine bakılması, fiziki yapının bağlama çalımına uygunluğu ve dinledikleri müzik türünün sorgulanması bu öntestin içeriğini oluşturmaktadır. Diğer 3 eğitmenin herhangi bir öntest yapmadığı görülmektedir. Bu 3 eğitmenden bir tanesi öntestin özengen müzik eğitimi veren kurumlarda yapılmasına gerek olmadığını, 2 tanesi ise Gençlik Merkezi ve KOMEK'te görev yaptıkları için müfredatlarında herhangi bir öntestin olmadığını belirtmişlerdir. Elde edilen verilere göre KOMEK ve Gençlik Merkezi dışındaki diğer özel müzik eğitimi kurumlarında öntest yapılması kurumların sadece para kazanma odakıı olmadığını, çalgıda başarı sağlanmasının hedeflendiğini göstermektedir.

- Bağlama derslerinin bireysel ya da grup dersi olacağını neye göre belirliyorsunuz? Şayet grup dersi veriliyorsa bir grup kaç öğrenciden oluşmaktadır ve bu sayı neye göre belirlenmektedir? E1: Grup dersi vermiyorum. Çünkü kişiler arasında algı, enstrüman çalışma süresi vb. farklılıklar neticesinde grup içi 
seviye farklılıkları meydana gelmesinin grup çalışmasını sekteye uğrattığını gözlemledim.

E2: Genelde dersler bireysel. Nota deşifre konusunda başarı sağlayan öğrenci ile grup çalışması yapıyoruz. Genelde sayı üçü geçmez. Burada ortak nokta deşifredir. Grup derslerine yönlendirdiğimiz öğrencilere öğrendiklerini diğer arkadaşlara göstermek şartı ile kendilerindeki gelişimin daha hızlı olacağına vurgu yaparız. Ayrıca grup dersinde ritim olgusu üzerine sohbetler ederek müziğin evrensel olmasında ritmin üstlendiği rolü izah ederiz.

E3: Çalıştığım eğitim merkezinde tüm dersler bireysel verilmektedir. Gurup derslerde verimin daha az olması, guruptaki kursiyerlerin yetenek anlamında farklılıklar göstermesi nedeniyle gurup ders eğitimi verilmemektedir.

E4: Eğitimlerimizde grup dersimiz mevcut değildir. Derslerimiz bireysel olarak gerçekleşmektedir.

E5: Bağlama derslerimiz bireysel olmaktadır.

E6: Gençlik Merkezi bünyesinde olduğu için mecburen grup dersi olarak verilmektedir. Bir grup 20 öğrenciden oluşmaktadır. Bu sayıda sınıfın öğrenci alabilme kapasitesine göre belirlenmektedir.

E7: Bă̆lama derslerimiz talep çoğunluğu nedeni ile grup dersleri olarak yapılmaktadır. Bir grup minimum 12 kişiden oluşmaktadır (halk eğitim merkezlerinin müfredatına göre) .

Bu soruya verilen cevaplara göre 5 eğitmen sadece bireysel olarak ders vermektedir. Bu konuda gerekçe olarak; kişiler arasında algı, enstrüman çalışma süresi vb. farklılıklar neticesinde grup içi seviye farklılıkları meydana gelmesinin grup çalışmasını sekteye uğrattığını, grup derslerinde verimin az olmasını, guruptaki kursiyerlerin yetenek anlamında farklılıklar gösterdiğini belirtmişlerdir. Diğer 2 eğitmen Gençlik Merkezi ve KOMEK'te görev yaptıkları için bireysel değil sadece grup dersi verdiklerini ifade etmişlerdir. Gruplardaki öğrenci sayıları Gençlik Merkezi'nde 20 kişi, KOMEK'te ise 12 kişi olarak ders verdiklerini belirtmişlerdir. Bu öğrenci sayılarını kendilerinin değil çalıştıkları kurum müfredatının belirlediğini açıklamışlardır. Bilinmektedir ki çalgı eğitimi bireysel olarak verilmelidir. KOMEK ve Gençlik Merkezi bünyesinde hem toplu olarak ders verilmesi hem de herhangi bir öntest yapılmadan öğrenci alımı sonucunda çalgı eğitimi alan öğrencilerde yeterli düzeyde bir ilerleme beklenemeyeceği ortadadır.

- Bağlama derslerine başlamadan önce bağlamayı tanıtıcı bilgiler veriyor musunuz? Veriyorsanız bu bilgiler ne gibi bir içerik taşımaktadır?

E1: Evet, veriyorum. Bă̆lamanın kısa tarihçesi, bağlamanın bölümleri, perdeleri, telleri, tutuşu vb. özelliklerdeki konulardan bahsediyorum.

E2: Çalgıların tamamına yakınının mühendisler fizikçiler vs... Bilim adamları tarafından icat edildiğinden bahsederek çalgının üzerindeki tellerin gerilimi eşik mesafesi ve bunların sesin oluşumuna nasıl sebep olduğu hakkında bilgiler verilir. La sesinden yola çıkarak doğadaki titreşim sayılarının notalara dönüşmesi anlatılır.

E3: Bağlamanın hem teknik olarak hem de tarihsel yapısıyla ilgili bilgiler verilmektedir.

E4: İlk dersimizde bağlama tarihçesi ve bağlama ailesi ayrıca bağlama yapıları hakkında bilgi veriyoruz.

E5: Bağlama derslerine başlamadan önce bağlama hakkında öğrencilerime bilgiler veriyorum. Tabi bu bilgileri verirken 
fazla derine inmiyorum yani bağlamanın tarihçesi vb. gibi. Sadece bağlamanın özellikleri hakkında bilgiler veriyorum.

E6: Bağlama nasıl tutulur, tuşelere nasıl basılır, nasıl doğru pozisyonda oturularak çalınır, doğru tutuş ve oturuş şekillerinin gösterilmesiyle ilgili bilgiler verilir. Bağlama hakkında temel bilgiler içeren konulara da değiniyoruz. Çaldıkları bağlama hangi malzemelerden üretiliyor boyutları olsun tel sayısı olsun perdelerin ne işe yaradığı konusunda olsun eşik olmasa tellerin işlevini yapmayacağı konusunda ve bağlama kültürümüze nerden gelip girdiği ile ilgili bilgiler veriyorum.

E7: İlk derslerimizde bağlama tarihçesi, çeşitleri, çalma teknikleri ve bu işin öncüleri olarak kabul görmüş kişiler hakkında bilgi veriyorum.

Tüm eğitmenler "evet tanıtıcı bilgiler veriyoruz" cevabını vermişlerdir. Bu bilgilerin içeriği olarak; bağlamanın kısa tarihçesi, bölümleri, perdeleri, telleri, bağlama ailesi ve bağlamanın yapılışı olarak belirtmişlerdir. Elde edilen bulgulara göre bağlama eğitim alacak bir öğrencinin bağlamanın tarihi, kısımları, yapımı vb. konularda bilgilendiriliyor olması olumlu bir sonuç olarak karşımıza çıkmaktadır. Bu durum hem öğrencinin genel kültürüne katkı sağlayacak hem de çalgısını daha iyi tanıyor olacaktır.

- Bă̆lama derslerine başlamadan önce veya dersler devam ederken öğrencilere nota okuma ve kuramla ilgili temel müzik bilgileri veriyor musunuz? Veriyorsanız bu bilgilerin içeriği nelerdir?

E1: Bağlama eğitimi ile nota okuma ve teori bilgilerini aynı paralellikte ilerletiyorum. 4lük, 8lik notalar ile başlayıp sadece bu materyaller ile bağlama üzerindeki perde yerlerini öğrenecekleri etüt ve kolay eserlerle başlıyorum. 16lık değerler konusuna geçildiğinde, o konuyu kapsayan etüt ve eserleri gündeme alıyorum. Özetle; çalınacak olan eserin içeriğini önce etüt edip, eserde uygulatmak şeklinde ilerliyorum.

E2: İlk olarak nota tartım dersleri ile başlıyoruz. Temel işaretler öğretilir. Tezene yönleri tartım matematiğine uygun olacak şekilde basit kesirler kullanarak anlatılır.

E3: Bă̆lama derslerine temel nota bilgileri verilerek başlanmaktadır. Akabinde tezene çalışmaları ve egzersizlerle devam edilmektedir.

E4: Eğitimlerimizde kulaktan eğitim yoktur. Tamamıyla nota eşliğinde derslerimizi yapıyoruz. Öncelikle temel nota eğitimi veriyoruz. Nota değerleri, tartım kalıpları ve nota yerleri hakkında bilgi veriyoruz, ayrıca bağlama üzerinde bunların uygulanması şeklinde devam ediyoruz.

E5: Öğrencilerime nota okuma ve kuramları öğretmekle başlatıyorum. Bunlar nota yerleri, süreleri, tartım vuruşları gibi bilgiler.

E6: Öncelikle derse başlamadan önce okuma tahtası üzerinde porte üzerinde notaları kavrama yöntemi şeklinde dersi anlatıyor ve notayı porte üzerinde daha rahat ve eğlenceli bir şekilde öğrenebilecekleri hale getirip notayı öğretiyorum. Her bir porte çizgisine aşağıdan başlayarak önce ana çizgi üzerindeki sesleri yazıyorum sonra arada kalan boşlukta kalan diğer notaları kavratıyorum ve ellerini bir porte gibi kullandırarak yolda giderken bile çalışabileceklerini söylüyorum. Tahta üzerinde gene hangi notanın vuruş süreleri ne kadar onları kavramaları yönünde şekilli kavrama yöntemiyle 1'lik notayı, 2 vuruşluk, 1 vuruşluk, yarım vuruşluk ve çeyrek vuruşluk notaları tanıtıp 
elleriyle zamanlarını ayrı ayrı vurdurtarak kavramalarını sağlıyorum.

E7: Temel nota eğitimi, tartım bilgisi, basit düzeyde solfej ve bona eğitimi veriyorum.

Bu soruya verilen cevaplara göre tüm eğitmenlerin nota okuma ve kuramla ilgili temel müzik eğitimi verdiği anlaşılmaktadır. Bu temel eğitimin içeriği ile ilgili; nota süreleri, temel tartım kalıpları, ses değiştirici ve nüans işaretleri, temel tezene yönleri ve akabinde küçük egzersiz ve etüt çalışmaları olarak belirtilmiştir. Bulgulara göre çalgı eğitimi öncesi ve devamında temel müzik eğitimi verilmesi olumlu bir sonuçtur. Özellikle çalınacak egzersiz, etüt ve eserlerin notadan deşifre yapılması konusunda büyük katkı sağlayacaktır.

- Bağlama derslerinde nota okuma ve kuramla ilgili temel müzik bilgileri vermeden sadece göstererek yaptırma veya kulaktan eğitim yöntemleri uyguladığınız öğrencileriniz var mı? Varsa bu öğrencilerde neden böyle bir yöntem uygulanmaktadır?

E1: Hayır, yok.

E2: Temel tartımlar üzerinde anlaştığımız öğrencilerin melodik hafızalarına güvendiklerimizle notaya bağlı kalmadan da çalışma yapıyoruz.

E3: Eğitimlerimiz tamamen nota üzerine olup kulaktan eğitim tercih edilmemektedir.

E4: Kulaktan eğitim uygulanmamaktadır.

E5: Kulaktan ya da göstererek gibi yöntemleri öğrencilerime uygulamıyorum.

E6: Hayır yok.

E7: Temel bilgiyi bütün öğrencilere veriyorum ama öğrencilerin algılamasında her hangi bir sınırlama olmadığı için temel müzik eğitimi bazı öğrenciler üzerinde etkili bir yöntem olmuyor. Her ne kadar uğraşmış olsam da öğrenci bilgiyi kabul etmiyor.

Bu sorunun cevabına göre tüm eğitmenler nota okuma ve kuramla ilgili temel müzik bilgileri vermeden sadece göstererek yaptırma veya kulaktan eğitim yöntemleri uyguladıkları herhangi bir öğrencilerinin olmadıklarını belirtmişlerdir. Bir önceki soruya verilen cevaplarda da belirtildiği gibi çalgı eğitimi sürecinde verilen temel müzik eğitimi bu sürecin olmazsa olmazıdır.

- Bağlama derslerinde egzersiz ve etütlerden faydalaniyor musunuz? Egzersiz ve etütlerin gerekliliği ile ilgili görüşleriniz nelerdir? Faydalanıyorsanız egzersiz ve etüt seçimini neye göre yapıyorsunuz?

E1: Evet, faydalanıyorum. Bă̆lama eğitiminde egzersiz ve etüt çalışmalarının çok gerekli olduğunu düşünüyorum. Örneğin, başparmak kullanımı eserde bir iki kere geçerken, bu amaca yönelik başparmağın çok kullanıldığı bir etüt hazırlayıp öğrenciyi bu davranışa hazırlıyorum. Böylelikle eser üzerinde bu davranışı kavramaktan ziyade etüt ile daha sağlıklı bir sonuç alıyorum.

E2: Daha çok eser çalışıyoruz. Egzersiz konusuna da eksikliğini hissettiğimiz durumlarda yöneliyoruz. Ama eser içinde gelişimi sağlamak öğrenciyi yönlendirme açısından daha mantıklı geliyor. Nedeni etüt egzersiz mantığında gelişen bir enstrümanımız olacağına geleneksel tavırların ve evrensel formların vurgulandığı icraya sahip bir sazımız olmasının daha iyi olacağıdır. Sadece egzersiz ve etüt konusunda ilerleme gösterip bir müzik eserini baştan sona icra edemeyecek icracıların varlığı söz konusu olduğu için böyle düşünmekteyiz .

E3: Evet faydalanıyorum. Kesinlikle günlük düzenli bir şekilde egzersiz yapılması düşüncesindeyim. Parmaklara bir nevi sporcu 
gibi düşünerek antrenman yaptırılması ve parmakların formda tutulması gerektiğini düşünüyorum. Egzersizleri öğrencilerin seviyelerine uygun olacak şekilde belirlemeye dikkat etmekteyim. E4: Öğrencinin gelişimi belirli bir noktaya gelinceye kadar birçok parmak egzersizi veriyoruz. Egzersiz ve etüt verilmeden yapılan çalışmaların sağlıkıı olacağını düşünmüyorum. Belirli bir gelişim tamamlanmadan (baskı-tutuş, parmak hareketleriteknik gibi) verilecek eserlerin çalımı esnasında ciddi problemler ve kalıcı yanlış teknikler oluşabilir. Önceliğim tekniksel aşamaları tamamlamak sonrasında eser çalımına geçmek.

E5: Öğrencilerime egzersiz ve etütler hakkında daha çok ağırlık veriyorum. Çünkü öğrencinin klavyede ve tezene vuruşlarında hakimiyet kazanması benim için önemlidir.

E6: Egzersiz ve etütlerden evet faydalanıyorum çünkü öğrencilerin daha temiz çala bilmeleri için parmak kaslarının yeteri ölçüde güçlü olması lazım. Bu yüzden seviyelerine göre önce küçük egzersizler ve etütler vererek hangi parmakları zayıfsa genelde 3 ve 4 numaralı parmaklara yönelik etüt ve egzersiz çalışmaları yaptırtıyorum.

E7: Etüt ve egzersizlerden faydalanıyorum. Çünkü parmak esnekliğinin çalımın daha güzel duyulmasında etkili olduğunu düşünüyorum. Kullandığım etütler aldığım eğitimler doğrultusunda öğrencilerin seviyelerine göre oluyor.

Bu soruya verilen cevaplara bakıldığında tüm eğitmenlerin egzersiz ve etütlerden faydalandığı görülmektedir. Bă̆lama eğitimi öğretiminde egzersiz ve etütlerin gerekliliği ile ilgili; çalınacak esere hazırlayıcılığı, mızrap hareketleri, yatay ve dikey çalışmalar, klavyedeki hakimiyet vb. konularda büyük destek sağladığı belirtilmiştir. Egzersiz ve etüt seçimiyle ilgili; çoğunlukla eser içerisindeki çalımda zorluk yaşanabilecek kısımlarla ilgili çalışmalar, bazen de eserle hiç alakası olmayan sadece kondisyon amaçlı egzersiz ve etütlerden seçtiklerini belirtmişlerdir. Her çalgıda olduğu gibi bağlamada da geliştirici egzersiz ve etütlerin kullanılması oldukça önem arz etmektedir. Sadece mesleki müzik eğitiminde değil özengen müzik eğitiminde de egzersiz ve etütlerden faydalanılması olması gereken bir sonuç olarak karşımıza çıkmıştır.

- Bağlama derslerinde egzersiz ve etütlerden faydalanıyorsanız bu etütleri hangi kişi ya da kaynaklardan elde ediyorsunuz? Kendiniz de egzersiz ve etüt yazıyor musunuz?

E1: Etütleri mevcut duruma göre kendim yazıyorum.

E2: Faydalandığım egzersizlerin çoğunu anlık olarak belirliyorum. Sayın Zeki ATAGÜR ve Sayın Attila ÖzdeK hoca tarafından yazılan eserleri tavsiye ediyoruz.

E3: Kullanmış olduğum tek bir kaynak yok. Farklı metot kitaplarından egzersizleri öğrencilere uygun olacak şekilde seçip uyguluyorum. Yeterli olmadığı durumlarda kendimde egzersizler verebiliyorum.

E4: Üniversitede hocalarımızdan aldığımız eğitimler esnasında öğrendiğimiz etütlerin yanı sıra dışarıda eğitim alanında güvendiğimiz kişilerin de oluşturdukları egzersizleri kullanıyorum. Ayrıca kendi oluşturduğum egzersizlerde bulunmaktadır.

E5: Öğrencilerime etüt ve egzersizleri aktarırken daha çok kendi birikimlerimden yararlanıyorum. Yardım aldığım kaynaklar tabiki oluyor. Bunlardan biride üniversitede hocam Attila ÖzDEK'in yazmış olduğu Bağlama İçin Etüt Egzersiz ve Eserler adlı kitabıdır. 
E6: Mehmet SAÇAN' IN kitabındaki alıştırmaları kullanıyorum ve kendi yazmış olduğum egzersizleri kullanıyorum.

E7: Etütlerimin bir kısmını üniversite de eğitim aldığım Attila ÖZDEK hocamın kitabından gösteriyorum. Ama kitap içeriği temel eğitim için biraz ağır olduğu için çoğunluğu kendi sadeleştirdiğim ve ürettim etütler oluşturuyor.

Bu soruya verilen cevaplara göre eğitmenlerin tamamı çalınacak esere ve öğrencinin seviyesine göre kendilerinin egzersiz ve etüt hazırladıklarını belirtmişlerdir. Bununla beraber eğitmenlerin egzersiz ve etütle ilgili kullandıkları kaynaklar konusunda; daha önce kendi hocalarından öğrendikleri egzersiz ve etütlerin yanı sıra Sayın Mehmet SAÇAN'ın, Sayın Zeki ATAGÜR'ün ve Sayın Attila ÖzDEK'in kaynaklarından da faydalandıklarını belirtmişlerdir. Bulgulara göre eğitmenler egzersiz ve etütlerle ilgili farklı kaynaklardan yararlansalar da kendilerinin de egzersiz ve etüt yazdıklarını belirtmişlerdir. Bu durum bağlama için egzersiz ve etütlerle ilgili kaynakların yetersizliğini ortaya koymaktadır.

- Bağlama derslerinde yöresel tezene tavırlarını öğretiyor musunuz? Yöresel tezene tavırlarının gerekliliği ile ilgili görüşleriniz nelerdir?

E1: Öğretiyorum. Bağlama enstrümanının doğası gereği yöresel tavırların öğrenilmesi gerekliliğine inanıyorum. Yöresel tavır ve üslupların uygulanmaması durumunda mandolin çalmak gibi bir durumun ortaya çıkacağını ve bağlamanın otantik ruhunun oluşmayacağını düşünüyorum.

E2: Bağlama halk çalgısıdır. Türk halkı birçok değişik unsurlardan oluşmuştur. Bu unsurları bir arada tutmaya yarayan çok önemli bir rolü olan bağlamanın yörelerimize ve insanlarına has çalım tekniklerini tavır adı altında öğretmek bağlama için olmazsa olmaz bir görevdir.

E3: Seviye olarak biraz daha ileride olan öğrencilerimle yöresel parçalarda çalışıyorum. Bă̆lama eğitimi alan öğrencilerin mutlaka yöresel tavırları öğrenmesi gerektiğini düşünüyorum.

E4: Yöresel tavırları belli aşamalara gelmiş öğrencilerime öğretiyorum. Türk halk müziği eserlerinde tavrın gerekliliği ve önemi tartışılmaz olup aynı zamanda icra edilen esere anlam ve duygu katması açısından da önemlidir.

E5: Öğrencilerimin bağlamada ilerlediğini tespit ettiğimde yöresel tavırlara geçme ihtiyacı duyuyorum. Çünkü Türk halk müziği eserlerinde yöreye has tezene vuruşlarıyla çalınması gerektiğinin kanaatindeyim.

E6: Evet öğretiyorum. Her yörenin kendine has bir tavrı üslubu vardır. Bu yüzden öğrencilerimde bu tavır ve üslupları bilmesinde büyük ölçüde faydalı olduğunu düşündüğüm için öğretmenin gerekli olduğunu düşünüyorum.

E7: Yöresel tezene tavırlarını öğretmiyorum. Ama tavırların önemi hakkındaki düşüncem bağlama milletimize özgü bir enstrüman. Bu nedenler bölgesel farklılıklarda kendini bariz bir şekilde belli eder. Tezene çeşitliliği bölge çokluğu ile alakalıdır diye düşünüyorum. Bu farklar da çalım çeşitlerini oluşturmaktadır.

Bu soruya verilen cevaplara göre tüm eğitmenlerin yöresel tezene tavırlarını öğrettiği görülmektedir. Yöresel tezene tavırlarının gerekliliği ile ilgili; bağlama çalgısının doğası gereği yöresel tezene tavırlarının öğretilmesi gerektiğini, yöresel tavırların uygulanmaması durumunda mandolin çalmak gibi bir durumun ortaya çıkacağını ve bağlamanın otantik ruhunun oluşmayacağını, Türk halkının birçok değişik unsurlardan oluştuğunu ve bu unsurları bir arada 
tutmaya yarayan çok önemli bir rolü olan bă̆lamanın yörelerimize has çalım tekniklerini tavır adı altında öğretmenin eğitmen için olmazsa olmaz bir görev olduğunu belirtmişlerdir.

- Bağlama derslerinde yöresel tezene tavırlarını öğretiyorsanız bu tavırları öğrettiğiniz sıraya göre sıralayınız. Bu sıralamayı neye göre yapıyorsunuz?

E1: Zeybek tavrını ilk olarak öğretiyorum. Öğrencinin bu tavırdaki durumuna göre orta Anadolu ve ardından Konya tavrı olarak ilerlemeyi uygun buluyorum.

E2: Teke Karadeniz Kayseri gibi yöreleri anlattıktan sonra Silifke Azeri tavırları ile güçlendirilerek Zeybek tavrı oluşturulur. En son hedef olarak Konya tavrı belirlenir. Konya tavrı tüm tavırların toplamı denebilir. En zor tavır olarak bilinir. Bununla birlikte öğrencinin kapasitesine göre bu sıra değişebilir.

E3: Öğrencilerin ilgi ve istekleri doğrultusunda hazır bulunuşluk düzeylerine göre seçim yapıyorum.

E4: İlk olarak zeybek tavrı ardında Konya, Yozgat ve diğer tavırlar. Ancak bu uzun bir eğitim olduğu için tüm tavırları tamamlayabildiğimiz öğrenci sayısı düşüktür. Tavır sıralanışları gelişim sürecine göre sıralanmaktadır. Verdiğim eğitimde bunu dikkate alıyorum. Öncelikle rahat kullanabileceğimiz tavırlardan başlayarak sağ bileğimizin olgunlaşmasından sonra aşama aşama öğrenciyi zorlayacak tavırlara geçiş yapıyorum.

E5: Yöresel tavırlarda kafamda belirlediğim sıra zeybek, teke gibi basit düzeyli tavırlarla başlamaktır.

E6: Zeybek, Sürmeli, Kayseri, Konya, Silifke, Azeri, Ankara, Aşıklama, Karadeniz, Rumeli, Karşılama ve Teke tavırlarını öğretiyorum. Bu sıralamayı ise öncelikle öğrencinin seviyesine ve kolaydan zora doğru sıralamalar şekline göre yapıyorum.

E7: Daha önce hiç tezene eğitimi vermedim. Ama verecek olursam çalım ve çırpma tekniklerine göre okulumda öğrenmiş olduğum sıralamayı kullanırım.

Bu soruya verilen cevaplara göre eğitmenlerin çoğu Zeybek, Konya, Teke, Karşılama, Sürmeli, Azeri, Silifke ve Aşık tavrı sıralamasını belirtmişlerdir. Eğitmenler bu sıralamayla ilgili daha önce kendi hocalarıyla çalıştıkları sıralamanın bu şekilde oluğunu, çoğu kaynakta bu şekilde bir sıralama olduğunu ve öğrencinin ilgi ve isteği göz önüne alınarak yapıldığını belirtmişlerdir.

- Bağlama derslerinde yöresel tezene tavırları öğretiyorsanız bu tavırlarla ilgili faydalandığınız kişi ya da kaynak var mı? Bunlar nelerdir?

E1: Kaynak kullanmıyorum. Eserleri repertuvardan ve etüteri kendimden kullanıyorum.

E2: Sosyal medyada çalınan tüm icraları değerlendiriyoruz.

E3: Bağlama hocam olan Hasan Hüseyin Genç başta olmak üzere faydalanmış olduğum TRT kaynakları ve farklı repertuvar kitaplarından faydalanıyorum. Ayrıca mahalli ve yöresel sanatçılardan eserleri dinleyip pekiştiriyorum.

E4: Usta çırak ilişkisine inandığım müzik eğitiminde bende kendi hocalarımın öğretileri doğrultusunda devam ediyorum. Yazılı bir kaynak eserlerin notaları haricinde kullanmıyorum.

E5: Yararlandığım bir kaynak yok. Üniversitedeki hocamın bana aktardığı bilgileri öğrencilerimle paylaşıyorum.

E6: Her hangi bir kişi yok sadece hangi tavrı işleyeceksem o yörenin müzik ve üsluplarını dinleyip müfredatta ki çalım şeklini öğrencilere gösterme ve uygulatma şeklinde tavırları işliyorum. 
E7: Bir önceki soruda cevapladığım gibi yöresel tezene tavrı öğretmiyorum.

Bu soruya verilen cevaplara bakıldığında eğitmenler yöresel tezene tavırlarıyla ilgili TRT repertuvarından, mahalli sanatçıların icra videolarından, daha önceki bağlama eğitimi aldıkları kurumlarda edindikleri bilgi ve tecrübelerinden, görsel ve sosyal medyadaki yöresel çalım stili ile ilgili görüntülerden faydalandıklarını belirtmişlerdir. Görülüyor ki artık günümüzde internetin aktif olarak kullanılması yöresel tavırların icraları konusunda en büyük kaynak olarak karşımıza çıkmaktadır.

- Bağlama derslerinde kullandığınız eserleri nereden temin ediyorsunuz? Eser seçimini neye göre yapıyorsunuz?

E1: TRT repertuvarından temin ediyorum. Eser düzeyini ise öğrencinin mevcut nota okuma durumuna göre belirliyorum. Yeni konuya etütle başlayıp eserle devam ediyorum.

E2: Yaygın olan eserler seçiyoruz. Güncel olmaya çalışıyoruz. Bununla birlikte birleşik usullerin içinde bulunduğu eserlerden faydalanıyoruz.

E3: Genel olarak TRT repertuarından belirlemeye çalışıyorum. Seçimi yine öğrencilerin seviyelerine uygun olacak şekilde kendi seçimleri doğrultusunda yapıyorum.

E4: TRT repertuvar kitabını kullanıyorum. Eser seçimini her öğrencinin seviyesine göre oluşturuyorum. Ancak kişilerin sanata ilgisinin artmasını sağlamak için bu repertuvar oluşturulurken karşılıklı istişarelerde de bulunuyoruz.

E5: Genellikle T.R.T T.H.M repertuvarından yararlanıyorum. Eser seçimini öğrencinin bağlamada gelişmişlik düzeyine göre belirliyorum. Fakat öğrencilerimin isteklerini de göz önünde bulunduruyorum.

E6: TRT arşivinden temin ediyorum. Eser seçimini gene öğrencilerin seviyelerine uygun eserler seçerek yapıyorum.

E7: TRT nota arşivinde seçiyorum. Eserlerin zorluk derecesine göre belirliyorum.

Bu soruya verilen cevaplara göre eğitmenler çoğunlukla TRT repertuvarına kayıtlı eserlerden temin ettikleri görülmektedir. Bunun yanı sıra TRT repertuvarında kayıtlı olmayan notası sosyal medyadan temin edilen bazı besteleri de kullandıklarını belirtmişlerdir. Eser seçimi ile ilgili çoğunlukla öğrenci seviyelerine bağlı olarak seçtiklerini belirtmişlerdir. Bunun yanı sıra öğrencinin derse devamını sağlayacak, onu motive edecek ve büyük bir hevesle çalmak isteyebileceği eserlerin seçiminden de bahsetmişlerdir. Bir önceki soruya verilen cevaplardan da elde edildiği gibi gerekli eserlere ulaşmada yine en büyük kaynak internettir. Eser seçimlerinin öğrencinin derse devamını sağlayacak ve motive edecek şekilde yapılması eğitimde bilinenden bilinmeyene, yakından uzağa yada çevreden evrene yöntemlerinin kullanıldığını göstermektedir.

- Bağlama derslerinde THM eserleri dışında başka müzik türlerinden de faydalanıyor musunuz? THM dışındaki müzik türlerinden faydalanılması gerekliliği ile ilgili görüşleriniz nelerdir? Faydalanıyorsanız hangi müzik türlerinden faydalandığınızı öğrettiğiniz sıraya göre sıralayınız.

E1: THM dışında bir müzik türünden faydalanmıyorum. Bağlama ile THM eserlerinin çalınması gerektiğini düşünüyorum.

E2: Bă̆lama ile günümüzde çalınabilecek eser sayısı bir hayli fazladır. Milli sazımız oluşu ve birçok bestecinin temelinde bağlama olması sebebi ile diğer müzik tarzlarında da bağlamaya çok yakın paragraflar mevcuttur. Saz semaisi, longa, sirto vs. formlar bağlama ile çok iyi çalınabilir. 
E3: Elbette farklı türlerin eserlerinin de öğretilmesi taraftarıyım. Longa ve sirtolar, deyişler, arabesk eserler ve çalınabilecek TSM eserleri gibi.

E4: Repertuarım sadece THM'nden oluşmamaktadır. Etüt mahiyetinde Orhan GENCEBAY eserlerinden de şarkı seçimi yapıyoruz. Bunun yanı sıra özgün müzikten de şarkılar seçiyorum. Çeşitlilik her zaman monotonluktan çıkarır müziği... Kişiler isterlerse kulaklarına hoş gelen yabancı bir eseri bile bağlamasıyla çalabilmelidir. Unutmayalım ki müzik her dalıyla güzeldir. Her yönüyle öğrencileri beslemek gerekir. Keyif alınır bir hale getirmekte biz eğitimcilere düşen görevdir. Ama yine de genel anlamda günümüzde değerinin bilinmesi açısından ve değerini yitirtmemek adına seçtiğim repertuvarın büyük bir bölümü THM eserlerinden oluşmaktadır.

E5: THM eserleri dışında farklı eserlerden yararlanıyorum. Bunlar saz semaileri, peşrevler, longalar gibi eserlerdir. Bunlardan yararlanmamın sebebi bağlamada performans geliştirmeye yönelik olmasıdır.

E6: Çalıştığım kurumda THM dışında eserlerden faydalanamıyoruz maalesef. Çünkü; 1. seviye ders verdiğimiz için öğrencileri zorlayıcı tekniklere yöneldiğimizde öğrenci sayılarında düşme oluyor. Ama ben tavırların ve THM'nin dışında öğrencilerime arpej'li çalışmalar yaptırıyorum.

E7: TSM arşivlerinde bulunan longalar ve sirtoları öğretiyorum. Pozisyon çeşitliliği ve etüt açışından çok gerekli olduğunu düşünüyorum.

Bu soruya verilen cevaba göre 1 eğitmen haricinde diğer 6 eğitmen THM dışında başka müzik türlerinden de faydalandığını belirtmişlerdir. Bahsi geçen 1 eğitmen bağlama çalımıyla ilgili THM eserlerinin yeterli olduğunu ve THM dışında başka müzik türlerinin özengen müzik eğitimi veren kurumlarda gerek olmadığını belirtmiştir. Diğer 6 eğitmen THM dışında tüm müzik türlerinden bağlamaya uyarlanabilecek eserlerin kullanılabileceğini aktarmışlardır. Ayrıca THM dışındaki türlerin THM eserlerini destekleyici mahiyette olması gerektiğini belirtmişlerdir. Örnek olarak saz semaileri, sirto ve longalar, batı müziği eserleri vb. olarak belirtilmiştir. Her ne kadar 1 eğitmen THM dışındaki müzik türlerinin bağlama eğitiminde kullanılmasını gerekli görmese de diğer tüm eğitmenler gerekli olduğunu ve kullandıklarını belirtmişlerdir. Bu durum artık bağlama eğitiminde sadece THM içerikli eserler değil THM dışındaki müzik türlerinin de icrasına yer verildiğini ispatlamıştır.

- Yukarıdaki soruların haricinde özengen müzik eğitimi kurumlarında bağlama öğretim yöntemleriyle ilgili eklemek istediğiniz herhangi bir şey var mi?

E1: Temel bağlama eğitimi ile ilgili kaynak eksikliğimizin olduğunu düşünüyorum. İçeriğinde seçme eserlerin kolaydan zora derlendiği ve bu eserlerin kapsamının etütlerle desteklendiği metodik bir çalışmanın bağlama eğitimi için acil ihtiyaç olduğunu düşünüyorum.

E2: Nota eğitimi ile alakalı konularda tereddütümüz var sadece. Nota eğitimi almamış kişiler tarafından açılan pek çok merkez mevcut. Kişilere uygulananın eğitim mi meşk mi olduğu konusunda kaygılıyız. Bu şekilde başlayan müzik hayatı verimsiz devam edecektir.

E3: Yapmış olduğunuz bu anket çalışması ve bu konuda benimde fikirlerini almış olmanızdan dolayı çok teşekkür eder iyi çalışmalar dilerim.

E4: Teşekkür eder, iyi çalışmalar dilerim. 
E5: Eklemek istediklerim; bağlamanın kulaktan veya göstererek öğretilmesi değil, notayla öğretilmesidir.

E6: Hayır yok. Bu güzel çalışma için sizlere teşekkür ediyorum.

E7: Maalesef ki Konya'da müziğe gerekli saygı gösterilmiyor. Toplumun gözünde bağlama kötü bir saz olarak görülüyor. Öyle ki maddi ucuzluğu ve çalma kolaylı olan bir saz olduğu için toplum tarafından sıradanlaştırılmıs. Bu yüzden kurum idaresi tarafında da yeterince önem gösterilmiyor. Bizler de bu sıradanlığı farklı türlerde eserler geçerek gidermeye çalıyoruz. Umarım toplumumuz hakettiği değeri gösterir.

Bu soruya verilen cevaplara bakıldığında 1 eğitmen temel bağlama eğitimi ile ilgili kaynak yetersizliğinden ve içeriğinde seçme eserlerin kolaydan zora derlendiği ve bu eserlerin kapsamının etütlerle desteklendiği metodik bir çalışmanın bağlama eğitimi için acil ihtiyaç olduğunu belirtmiştir. Diğer eğitmenler teşekkür ederek anketi sonlandırmışlardır.

\section{2. İlgili Yayınlar (Related Publications)}

(Hancıoğlu, 2010) "Ankara'daki Özengen (Amatör) Müzik Eğitimi Veren Kurumların Eğitim Anlayışları Ve Yönetim Biçimleri Üzerine Genel Bir Inceleme" isimli yüksek lisans tezinde, Ankara'daki özengen (amatör) müzik eğitimi veren kurumların eğitim anlayışları ve yönetim biçimleri incelenmiştir. Amatör müzik eğitimi veren kurumların yöneticileri ve bu kurumlarda ders alan öğrencilerin, kurum hakkında farklı fikirlerinin olduğu düşünülerek, görüşler arasında farklılık olup olmadığını tespit etmek amacıyla kurum yöneticilerine ve öğrencilere farklı anketler uygulanmıştır. Bulgular, özengen müzik eğitimi veren kurumlarda ortak bir eğitim anlayışı ve öğretim programı olmadığı yönünde tespit edilmiştir. Ortak bir öğretim programı ve eğitim anlayışı olsa bile denetimler sadece yönetim tarafından zaman zaman yapılmadığı görülmüştür. Kurumlarda çalışacak kişilerin genellikle mesleki deneyimlerine bakılarak temin edildiği, ancak bu kurumların ticari kaygı taşımasından dolayı mesleğinde etkin olmayan lisans öğrencilerinin de bu kurumlarda öğretmenlik yaptığı sonucuna ulaşılmıştır.

(Karan, 2011) "Özengen Müzik Eğitimi Veren Kurumlarda Çalgı Eğitimi Alan Öğrencilerin Mesleki Yönelimlerinin İncelenmesi" isimli yüksek lisans tezinde özengen müzik eğitimi veren kurumlarda verilen çalgı eğitiminin öğrencilerin mesleki yönelimlerine etkisi saptanmaya çalışılmıştır. Bu çalışmada, özengen müzik eğitimi veren kurumlarda çalgı eğitimi alan öğrencilerin mesleki yönelimlerini saptamak için, özengen çalgı eğitimi veren bir kurumda 75 öğrenciye 13, 75 veliye 14 sorudan oluşan anket uygulanmıştır. Araştırma sonucunda, özengen müzik eğitimi veren kurumlarda çalgı eğitimi alan öğrencilerin, çoğunlukla kendi istekleri ve ailelerinin teşviki ile başladıkları, severek ve isteyerek devam ettikleri ve zorunlu olmadıkça devamsızlık yapmadıkları görülmüştür. Öğrencilerin çalgı eğitimine başladıktan sonra kendi dinledikleri müzik dışındaki müzik türlerine de ilgi duymaya başladıkları ve çevrelerindeki müzik etkinliklerine katılımlarının arttığı saptanmış, ileride müziğe meslek olarak yönelme düşüncesinde oldukları ve öğrenci velilerinin de çocuklarının ileride müziği meslek olarak seçmesini tercih ettikleri sonucu ortaya çıkmıştır. Bu bulgular sonucunda Türkiye'de özengen müzik eğitimi kurumlarında verilen çalgı eğitimine yönelik önerilerde bulunulmuştur.

(Çă̆lar, 2011) "Özengen Keman Eğitimi Alan Öğrencilerin Temel Hedeflere Erişme Düzeylerinin Çeşitli Değişkenler Açısından İncelenmesi (Bir Müzik Kursu Örneği)" isimli doktora tezi, çeşitli değişkenlerin özengen keman eğitiminde öğrencilerin temel hedeflere 
erişme düzeylerine etkisinin belirlenmesi amacıyla yapılmıștır. Araştırma Ankara'da özel bir müzik kursunda ilk kez özengen keman eğitimi gören 24 kişilik bir örneklem grubu üzerinde gerçekleştirilmiştir. Araştırmada öğrencilerin temel hedeflere erişme düzeyleri yaş, cinsiyet ve süreç değişkenleri bakımlarından incelenmiştir. Araştırmanın gerektirdiği öğretim süreci ve verilerin toplanması için uzman görüşleri alınarak iki dönemlik bir öğretim programı ile dönem sonlarında uygulanmak üzere bilişsel ve devinişsel testler hazırlanmıştır. Sonuç olarak özengen keman eğitiminin temel hedeflerine erişmede yaş ve cinsiyetin önemli bir etken olmadığı, sürecin ise önemli bir etken olduğu görülmüştür. Özengen keman eğitiminde bu değişkenlerin bu sonuçlarla değerlendirilip rehberlik edilmesi gerektiği, bu tür araştırmaların, başka örneklem grupları ve başka çalgılar üzerinde de yapılmasının yararlı olacağı önerilerinde bulunulmuştur.

(Yavşin, 2011) "İlköğretim Öğrencilerinin Özengen Çalgı Eğitimi Konusundaki Yönelimlerinin Belirlenmesi" isimli yüksek lisans tezi ilköğretim 4, 5, 6, 7 ve 8. sınıf öğrencilerinin özengen çalgı eğitimi alma durumlarının belirlenmesini ve özengen çalgı eğitiminin bazı değişkenlerle olan ilişkisini tespit etmeyi amaçlamıştır. Araştırmanın yöntemiyle ilgili İstanbul'da toplam dokuz okul seçilmiş, seçilen bu okulların 4, 5, 6, 7 ve 8. sınıflarında öğrenim görmekte olan 1204 öğrenciye anket uygulanmıştır. Elde edilen bulgular ışığında, ilköğretim öğrencilerinin büyük çoğunluğunun (\%91) özengen çalgı eğitimi almadığı, özengen çalgı eğitiminde en çok tercih edilen çalgının gitar olduğu, öğrencilerin çoğunun (\%67.5) imkanları olması halinde çalgı eğitimi almak istedikleri, özengen çalgı eğitimi alma durumunun ailelerin sosyoekonomik ve sosyokültürel düzeyleri ile anlamlı derecede ilişkili olduğu, özengen çalgı eğitimi alma durumunun öğrencilerin dinledikleri müzik türleriyle ilişkili olduğu, ilköğretim öğrencilerinin en çok dinledikleri müzik türlerinin pop ve rap müzik olduğu sonuçlarına ulaşılmıştır.

(Ceviz, 2014) "Özengen Müzik Eğitimi Veren Kurumlarda Uygulanan Gitar Eğitiminde Kullanılan Kaynakların İncelenmesi" isimli yüksek lisans tezi, Ankara'da özengen müzik eğitimi veren Sem Müzik Kursu, Senkron Müzik Kursu, Nesibe Aydın Sanat Kursu, Hayal Sahnesi Sanat Kursu ve Ankanom Müzik Kursu'nda uygulanan klasik gitar eğitiminde kullanilan metotlar, notalar ve diğer kaynakların incelenmesini hedeflemiştir. Araştırmada örneklemi oluşturan kurumların eğitmenleriyle görüşmeler yapılmış ve anket tekniği uygulanarak öğretimde kullandıkları metot, nota ve diğer kaynakların belirlenmesi sağlanmıştır. Elde edilen veriler bağlamında, kurumlarda kullanılan yedi metodun incelemesi yapılmıştır.

(Özdek, 2006) "Özengen Müzik Eğitimi $\square$ Veren Kurumlarda Klasik Gitar Eğitimi" isimli yüksek lisans tezi ülkemizde özengen müzik eğitimi kurumları içerisinde klasik gitar eğitiminde kullanılan metot ve yöntemlerin, eğitmen ve öğrenci tutumlarının, hedeflerin ve bu süreçte ortaya çıkan problemlerin belirlenmesi ve çözüm önerileri oluşturulabilmesi amacıyla yapılmıştır. Bu amaçla araştırmayla ilgili kaynaklar incelenerek 6 coğrafi bölgede 16 ilden, müzik eğitimi veren 50 kurumdaki 55 klasik gitar eğitimcisine 12 çoktan seçmeli ve 1 açık uçlu toplam 13 sorudan oluşan bir anket uygulanmıştır. Değerlendirme sonunda; özengen müzik eğitimi veren kurumların bir araya gelerek kendi kendilerini denetleme sistemini de içeren bir ortak yapıda örgütlenmesinin, bu kurumların salt ticari kaygılardan oluşan yaklaşımlardan arındırılmasının ve nitelikli bir özengen müzik eğitimi için alanında yeterli birikime sahip eğitimcilerin bulunduğu bir istihdam ortamının yaratılmasının gerekliliği ortaya çıkmıştır. 


\section{SONUÇLAR (RESULTS)}

- Araştırmayla ilgili Konya'da özengen müzik eğitimi kurumlarında bağlama derslerini yürütmekte olan toplam 11 eğitmene anket gönderilmiştir. Bu 11 eğitmenden 4'ü sebep belirtmeksizin ankete katılmamışlardır. Sonuçta ulaşılabilen 7 farklı özengen müzik eğitimi kurumu ve bu kurumlarda fiilen bağlama derslerini yürütmekte olan eğitmenlere anket uygulanmıştır. Anket uygulanan kurumlardan 5'i özel müzik eğitimi kurumu, 1'i Gençlik Merkezi, 1'i de Konya Büyükşehir Belediyesi'ne bağlı Konya Meslek Edindirme Kursu (KOMEK) olarak karşımıza çıkmıştır.

- Elde edilen bulgulara bakıldığında Gençlik Merkezi ve KOMEK ile diğer özengen müzik eğitimi veren kurumlar arasında haftalık ders saati, bir ders saati süresi ve dersin bireysel yada toplu verilmesi gibi birçok yönden farklılıklar ortaya çıkmıştır.

- Bazı özengen müzik eğitimi kurumlarında bağlama öğrencisi alırken öğrenciye temel müzik bilgileri, müziksel kabiliyetleri ve çalgıya yatkınlığı vb. konularda herhangi bir öntestin yapılmadığı görülmüştür.

- Elde edilen bulgulara göre 5 özengen müzik eğitimi kurumu kişiler arasında algı, enstrüman çalışma süresi vb. farklılıklar neticesinde grup içi seviye farklılıkları meydana gelmesi, grup derslerinde verimin az olması, guruptaki kursiyerlerin yetenek anlamında farklılıklar göstermesi gerekçeleriyle dersleri bireysel olarak yürüttüğü sonucuna ulaşılmıştır. Diğer 2 kurumda ise bir ders saatinde Gençlik Merkezi'nde 20, KOMEK'te 12 öğrenciyle ders yapıldığı sonucuna ulaşılmıştır.

- Gençlik Merkezi ve KOMEK'te herhangi bir öntest yapılmaksızın bağlama öğrencisi kabul edildiği ve derslerin bireysel değil toplu olarak yürütülmeye çalışıldığı karşımıza çıkmaktadır. Bu kurumların haricindeki tüm özengen müzik eğitimi merkezlerinde bağlama dersinin bireysel olarak yürütüldüğü sonucuna ulaşılmıştır. Ayrıca ulaşılan tüm kurumlarda bağlama dersine başlamadan önce bağlamanın kısa tarihçesi, bölümleri, perdeleri, telleri, bağlama ailesi ve bağlamanın yapılışı gibi temel bilgilerin verildiği sonucuna ulaşılmıştır.

- Ulaşılabilen özengen müzik eğitimi kurumlarının tümünde bağlama eğitimi-öğretimi sürecinde nota süreleri, temel tartım kalıpları, ses değiştirici ve nüans işaretleri, temel tezene yönleri ve akabinde küçük egzersiz ve etüt çalışmaları gibi temel müzik eğitimi de verildiği sonucuna ulaşılmıştır. Nota okuma ve kuramla ilgili temel müzik bilgileri vermeden sadece göstererek yaptırma veya kulaktan eğitim yöntemleri uygulanan herhangi bir öğrencinin olmadığı sonucuna ulaşılmıştır. Ayrıca çalınacak esere hazırlayıcılığı, mızrap hareketleri, yatay ve dikey çalışmalar, klavyedeki hakimiyet vb. konularda büyük destek sağladığı gerekçeleriyle egzersiz ve etütlerden faydalanıldığı sonucuna ulaşılmıştır. Eğitmenlerin egzersiz ve etüt seçimiyle ilgili; çoğunlukla eser içerisindeki çalımda zorluk yaşanabilecek kısımlarla ilgili çalışmalar, bazen de eserle hiç alakası olmayan sadece kondisyon amaçlı egzersiz ve etütlerden seçtiği sonucuna ulaşılmıştır.

- Anket uygulanan kurumlarda egzersiz ve etütlerle ilgili Mehmet Saçan, Zeki Atagür ve Attila Özdek'e ait kaynaklardan yararlanıldığı görülse de çoğunlukla eğitmenlerin çalınacak esere ve öğrencinin seviyesine göre kendi yazdıkları egzersiz ve etütlerden faydalandıkları sonucuna ulaşılmıştır. Bu sonuca göre bağlama için egzersiz ve etütle ilgili kaynakların yetersiz olduğu sonucu çıkmıştır. 
- Anket uygulanan tüm kurumlarda, yöresel tezene tavrı kullanılarak eser çalımı yapıldığı görülmüştür. Bu tezene tavırları; Zeybek, Konya, Teke, Karşılama, Sürmeli, Azeri, Silifke ve Aşık tavrı olarak karşımıza çıkmaktadır. Bu tavırların öğretimiyle ilgili TRT repertuvarı, mahalli sanatçıların icra videoları, daha önceki bağlama eğitimi aldıkları kurumlarda edindikleri bilgi ve tecrübeler, görsel ve sosyal medyadaki yöresel çalım stili ile ilgili görüntüler kaynak olarak kullanıldığı sonucuna ulaşılmıştır. Ayrıca öğrencilerin sevilerine uygun olarak seçilen eserlerin TRT repertuvarında kayıtı ya da kayıtıı olmayıp sosyal medya üzerinden temin edildiği sonucuna ulaşılmıştır.

- Özengen müzik eğitimi kurumlarında bağlama eğitimi-öğretiminde THM dışında tüm müzik türlerinin bağlamaya uyarlanabilecek eserlerinden de faydalanıldığı sonucuna ulaşılmıştır.

- Sonuç olarak Konya'da özengen müzik eğitimi veren 7 kurumda bağlama dersleri meşk (usta-çırak) yöntemi ile yürütülmektedir. Öğretim yöntemi sürecinde nota öğretimi yapılarak eser çözümü sağlanmakta ancak eserin bütünüyle ve yöresine has bir çalımı için meşk yöntemi devreye girmektedir.

\section{6. ÖNERILER (SUGGESTIONS)}

- Bu araştırmayla ilgili daha geniş kapsamlı ve sağlıklı sonuçlar alınabilmesi için diğer illerde ve daha fazla örneklem grubuyla çalışılması önerilmektedir.

- Özengen müzik eğitimi veren tüm kurumların birbirleriyle organize hareket ederek, haftalık ders saatleri, ders süreleri gibi konularda ortak bir program çerçevesinde ilerlemeleri önerilmektedir.

- Gençlik Merkezi ve KOMEK gibi özengen müzik eğitimi kurumlarında toplu olarak verilen çalgı eğitiminin verimsiz olacağı aşikardır. Hangi platformda olursa olsun tüm çalgılarda olduğu gibi bağlama eğitimi ve öğretimi de bireysel olarak verilmelidir.

- Özengen müzik eğitimi veren kurumlarda bağlama eğitimi alacak öğrenci seçilirken maddi kazanç gütmeden gerekli öntest yapılarak seçilmesinin daha verimli bir eğitim süreci olacağı düşünülmektedir.

- Bağlama eğitimi ve öğretimi sürecinde bağlama hakkında tarihsel süreci, kısımları, yapılışı gibi tanıtıcı bilgilerin verilebileceği önerilmektedir.

- Daha sağlıklı bir çalgı eğitimi süreci için bağlama eğitimi ve öğretimine başlamadan önce veya süreç içerisinde temel müzik bilgilerinin verilmesi çalgıyı sadece kulaktan öğretim yöntemiyle değil notadan deşifre yaparak da öğretilmesinin doğru bir yöntem olacağı önerilmektedir.

- Bağlama eğitimi öğretimi sürecinde esere hazırlayıcı mahiyette egzersiz ve etütlerden faydalanılması gerektiği önerilmektedir. Ayrıca bu araştırmalar sayesinde ortaya çıkan egzersiz ve etütler için kaynak yetersizliği konusunda gerekli çalışmaların yapılması önerilmektedir.

- Bağlamada yöresel tezene tavırlarından faydalanılacağı gibi THM dışındaki tüm müzik türlerinin bağlamaya uyarlanarak kullanılabileceği önerilmektedir. 


\section{KAYNAKLAR (REFERENCES)}

- Ceviz, B., (2014). Özengen Müzik Eğitimi Veren Kurumlarda Uygulanan Gitar Eğitiminde Kullanılan Kaynakların Incelenmesi, Yüksek Lisans Tezi, Gazi Üniversitesi Eğitim Bilimleri Enstitüsü.

- Çağlar, E., (2011). Özengen Keman Eğitimi Alan Öğrencilerin Temel Hedeflere Erişme Düzeylerinin Çeşitli Değişkenler Açısından Incelenmesi (Bir Müzik Kursu Örneği), Doktora Tezi, Gazi Üniversitesi Eğitim Bilimleri Enstitüsü.

- Hancıoğlu, G., (2010). Ankara'daki Özengen (Amatör) Müzik Eğitimi Veren Kurumların Eğitim Anlayışları Ve Yönetim Biçimleri Üzerine Genel Bir İnceleme, Yüksek Lisans Tezi, Gazi Üniversitesi Eğitim Bilimleri Enstitüsü.

- Karan, M., (2011). Özengen Müzik Eğitimi Veren Kurumlarda Çalgı Eğitimi Alan Öğrencilerin Mesleki Yönelimlerinin İncelenmesi, Yüksek Lisans Tezi, Gazi Üniversitesi Eğitim Bilimleri Enstitüsü.

- Kınık, M., (2010). Güzel Sanatlar Fakülteleri Müzik Bölümlerinde Bağlama Dersi Başlangıç Düzeyine Yönelik Öğretim Programı Önerisi, Doktora Tezi, Selçuk Üniversitesi Eğitim Bilimleri Enstitüsü

- Kurtuldu, K., (2005). Bilgiyi İşleme Modeline Dayalı Öğrenmenin Piyano Eğitimi Açısından Değerlendirilmesi, Müzik Sempozyumu. Kayseri: Erciyes Üniversitesi Güzel Sanatlar Fakültesi Müzik Bölümü .

- Özdek, A., (2006). Özengen Müzik Eğitimi Veren Kurumlarda Klasik Gitar Eğitimi, Yüksek Lisans Tezi, Selçuk Üniversitesi Sosyal Bilimler Enstitüsü.

- Özdek, A., (2012). Özengen Müzik Eğitim Kurumlarında Verilen Gitar Eğitiminde Veli ve Öğrenci Beklentilerine Yönelik Bir Araştırma: Kayseri Örneği, Niğde 10.Müzik Eğitimi Sempozyumu, 25-27 Nisan, Niğde.

- Parasız, P., (2009). Keman Öğretiminde Kullanılmakta Olan Çağdaş TürkMüziği Eserlerinin Seslendirilmesine Yönelik Olarak Oluşturulan Hazırlayıcı Alıştırmaların İşgörüsellik ve Etkililik Yönünden İncelenmesi, Doktora Tezi, Ankara Gazi Üniversitesi.

- Tanrıöver, A.U. ve Başaran Tanrıöver, G., (2015). Genel Özengen Ve Mesleki Müzik Eğitimi Süreci İçinde Verilen Keman Eğitiminde Karşılaşılabilecek Olası Güçlükler: International Journal of Social Science, Cilt:32, Sayl:3, ss:555-567, Doi: http://dx.doi.org/10.9761/JASSS2679.

- Tarman, S., (2006). Müzik Eğitiminin Temelleri(1.Baskı). Ankara: Müzik Eğitimi Yayınları.

- Uçan, A., (1997). Müzik Eğitimi Temel Kavramlar-İlkelerYaklaşımlar ve Türkiye' de Cumhuriyetin ilk Altmıs Yılındaki Durum, Ankara, Müzik Ansiklopedisi Yayınları.

- Uçan, A., (2005). Müzik Eğitimi: Temel Kavramlar-İlkelerYaklaşımlar ve Türkiye'deki Durum, Ankara: Evrensel.

- Uslu, M., (1996). Türkiye'de Çalgı Eğitiminin Yaygınlaştırılmasında ve Geliştirilmesinde Çok Seli Müzik Eğitimi Görüşü, II. Ulusal Eğitim Sempozyumu, İstanbul: Marmara Üniversitesi Atatürk Eğitim Fakültesi.

- Yavşin, A.N., (2011). İlköğretim Öğrencilerinin Özengen Çalgı Eğitimi Konusundaki Yönelimlerinin Belirlenmesi, Yüksek Lisans Tezi, Marmara Üniversitesi Eğitim Bilimleri Enstitüsü. 